\title{
Mutation spectrum of EXT1 and EXT2 in the Saudi patients with hereditary multiple exostoses
}

\author{
Zayed Al-Zayed ${ }^{1,2}$, Roua A. Al-Rijjal ${ }^{3}$, Lamya Al-Ghofaili², Huda A. BinEssa3 ${ }^{3}$, Rajeev Pant ${ }^{1}$, Anwar Alrabiah ${ }^{1,2}$, \\ Thamer Al-Hussainan ${ }^{1,2}$, Minjing Zou ${ }^{3}$, Brian F. Meyer ${ }^{3}$ and Yufei Shi ${ }^{3^{*}}$ (D)
}

\begin{abstract}
Background: Hereditary Multiple Exostoses (HME), also known as Multiple Osteochondromas (MO) is a rare genetic disorder characterized by multiple benign cartilaginous bone tumors, which are caused by mutations in the genes for exostosin glycosyltransferase 1 (EXT1) and exostosin glycosyltransferase 2 (EXT2). The genetic defects have not been studied in the Saudi patients.
\end{abstract}

Aim of study: We investigated mutation spectrum of EXT1 and EXT2 in 22 patients from 17 unrelated families.

Methods: Genomic DNA was extracted from peripheral leucocytes. The coding regions and intron-exon boundaries of both EXT1 and EXT2 genes were screened for mutations by PCR-sequencing analysis. Gross deletions were analyzed by MLPA analysis.

Results: EXT1 mutations were detected in 6 families (35\%) and 3 were novel mutations: c.739G >T (p. E247*), c.1319delG (p.R440Lfs*4), and c.1786delA (p.S596Afs*25). EXT2 mutations were detected in 7 families (41\%) and 3 were novel mutations: c.541 delG (p.D181 lfs*89), c.583delG (p.G195Vfs*75), and a gross deletion of approximately $10 \mathrm{~kb}$ including promoter and exon 1. Five patients from different families had no family history and carried de novo mutations (29\%, 5/17). No EXT1 and EXT2 mutations were found in the remaining four families. In total, EXT1 and EXT2 mutations were found in 77\% (13/17) of Saudi HME patients.

Conclusion: EXT1 and EXT2 mutations contribute significantly to the pathogenesis of HME in the Saudi population. In contrast to high mutation rate in EXT 1 (65\%) and low mutation rate in EXT2 (25\%) in other populations, the frequency of EXT2 mutations are much higher (41\%) and comparable to that of EXT1 among Saudi patients. De novo mutations are also common and the six novel EXT1/EXT2 mutations further expands the mutation spectrum of HME.

Keywords: EXT1, EXT12, Mutation, Exostoses, Osteochondromas

\section{Introduction}

Hereditary Multiple Exostoses (HME) or Multiple Osteochondromas $(\mathrm{MO})$ is a rare autosomal-dominant pediatric disorder with an incidence of about 1 in 50,000

\footnotetext{
*Correspondence: yufei@kfshrc.edu.sa

${ }^{3}$ Department of Genetics, MBC 3, Centre for Genomic Medicine, King Faisal Specialist Hospital and Research Center, P.O. Box 3354 Riyadh 11211, Saudi Arabia

Full list of author information is available at the end of the article
}

individuals and male-to-female ratio of about 1.5:1 [1, 2]. The disease is characterized by the development of two or more cartilage capped bony outgrowths within perichondrium in long bones and ribs, which can cause a variety of orthopedic deformities such as disproportionate short stature, shortened forearms, and unequal limb length. Although it is generally a benign skeletal tumor, $2.8 \%(0.5-5 \%)$ of patients undergo malignant transformation towards life-threatening chondrosarcomas or original author(s) and the source, provide a link to the Creative Commons licence, and indicate if changes were made. The images or other third party material in this article are included in the article's Creative Commons licence, unless indicated otherwise in a credit line to the material. If material is not included in the article's Creative Commons licence and your intended use is not permitted by statutory regulation or exceeds the permitted use, you will need to obtain permission directly from the copyright holder. To view a copy of this licence, visit http://creativecommons.org/licenses/by/4.0/. The Creative Commons Public Domain Dedication waiver (http://creativeco mmons.org/publicdomain/zero/1.0/) applies to the data made available in this article, unless otherwise stated in a credit line to the data. 
osteosarcomas due to their typical resistance to chemoor radiation therapy $[3,4]$.

Germline heterozygous loss-of-function mutations in the EXT1 (exostosin-1, located on chromosome 8q23-q24) or EXT2 (exostosin-2, located on chromosome 11p11-p12) tumor suppressor genes are responsible for over $70-95 \%$ of HME cases [5, 6]. There are 566 EXT1 and 278 EXT2 mutations reported in the literature (HGMD database). The majority of these mutations (79\% in EXT1 and 75\% in EXT2) are frameshift, nonsense, and splice-site mutations, resulting in truncated proteins [5]. About $65 \%$ of the mutations occur in EXT1 and $25 \%$ in EXT2. In about $10-15 \%$ of HME cases, genomic alterations cannot be detected by the conventional method due to alterations such as intronic deletions, translocations or somatic mosaicism $[7,8]$. The involvement of other genes or the putative EXT3 gene on chromosome 19 still needs investigation.

The genetic defects causing HME have not been systematically investigated in the Arab population. In the present study, we performed molecular analysis of 22 patients from 17 unrelated Saudi families with HME. EXT1 or EXT2 mutations were identified in $77 \%$ of patients (13/17) including six novel mutations.

\section{Subjects and methods}

\section{Patients}

Seventeen Saudi families with HME were investigated (Fig. 1 and Table 1). The inclusion criteria were two or more exostoses diagnosed upon physical and radiographic examinations. Disease severity was divided into 3 classes based on the presence of skeletal deformities and functional limitations using the following criteria: Class I: no deformities and no functional limitations $[\mathrm{A} \leq 5$ sites with osteochondromas, $\mathrm{B}>5$ sites with osteochondromas]; Class II: deformities and no functional limitations $[\mathrm{A} \leq 5$ sites with deformities, $\mathrm{B}>5$ sites with deformities]; and Class III: deformities and functional limitations [A functional limitation of 1 site, $B$ functional limitation of $>1$ site] [9]. Blood samples were obtained from patients and available relatives for genomic DNA extraction after informed consent. The study was approved by the Ethics Committee of King Faisal Specialist Hospital and Research Centre (RAC \# 2170 027). Written consent was obtained from the patients or guardian of the patients before enrollment.

\section{Genomic DNA isolation}

Genomic DNA from peripheral blood leukocytes was extracted as described previously [10].

\section{DNA amplification and sequencing}

DNA samples were analyzed for mutations in all the coding exons and intron-exon boundaries of EXT1 and EXT2 genes by polymerase chain reaction (PCR) and sequencing analysis. PCR primers and conditions were described previously and listed in Table 2 [11]. The resulting PCR products were directly sequenced with BigDye Terminator 3.1 Cycle Sequencing kit using an automated ABI PRISM 3700 sequencer (Applied Biosystems; Life Technologies, Foster City, CA).

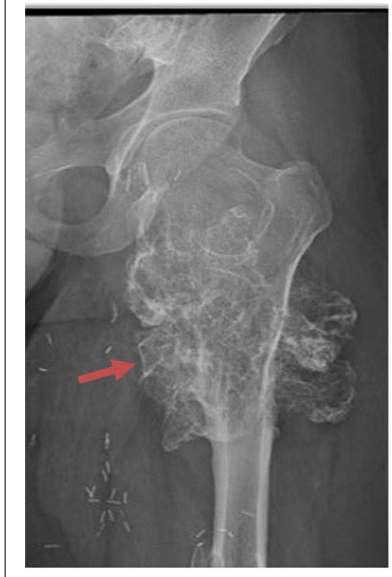

Patient \# 1

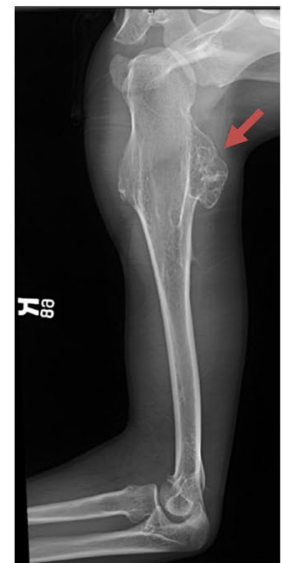

Patient \# 15

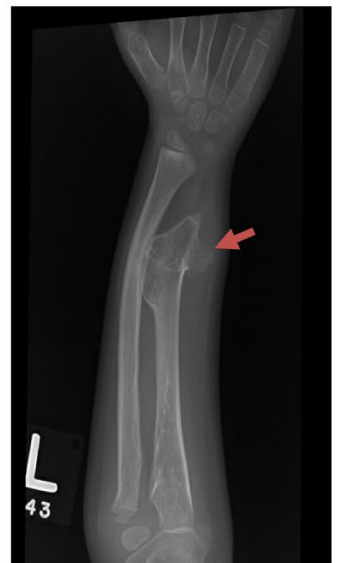

Patient \# 18

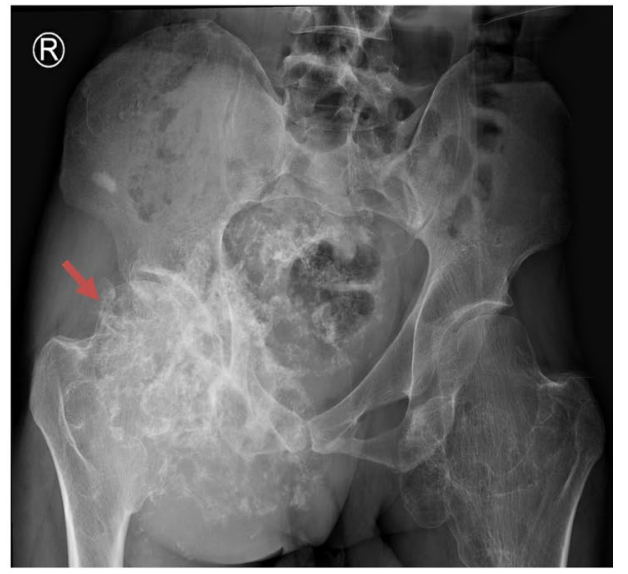

Patient \# 21

Fig. 1 Radiology of patients with osteochondromas. Patient\#1 has an osteochondroma at left hip joint; Patient \#15 has an osteochondroma at right proximal humerus; Patient\#18 has an osteochondroma at left distal radius; and Patient \# 21 has a right pelvic osteochondroma with malignant transformation. Osteochondroma is indicated by an arrow 


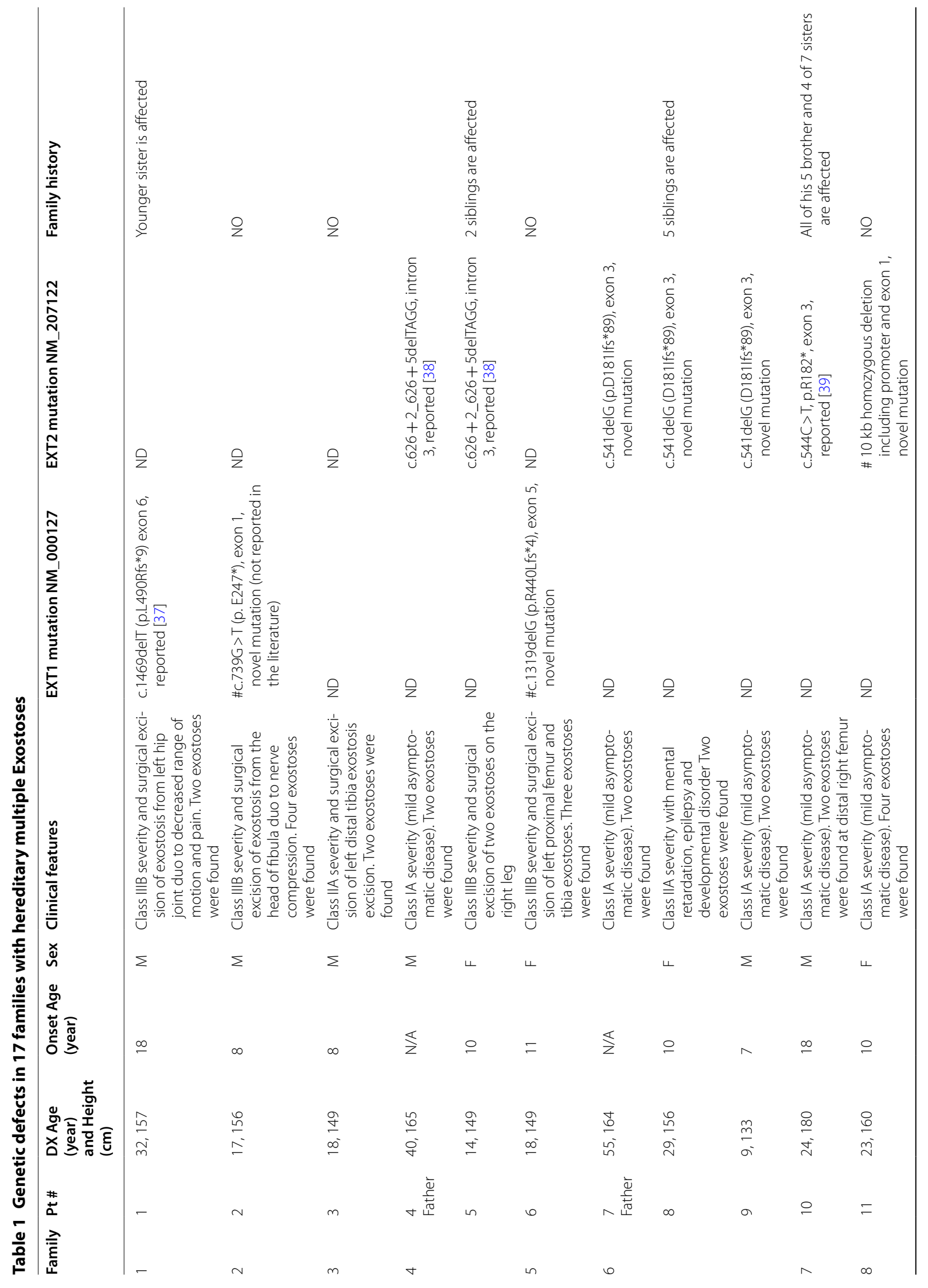




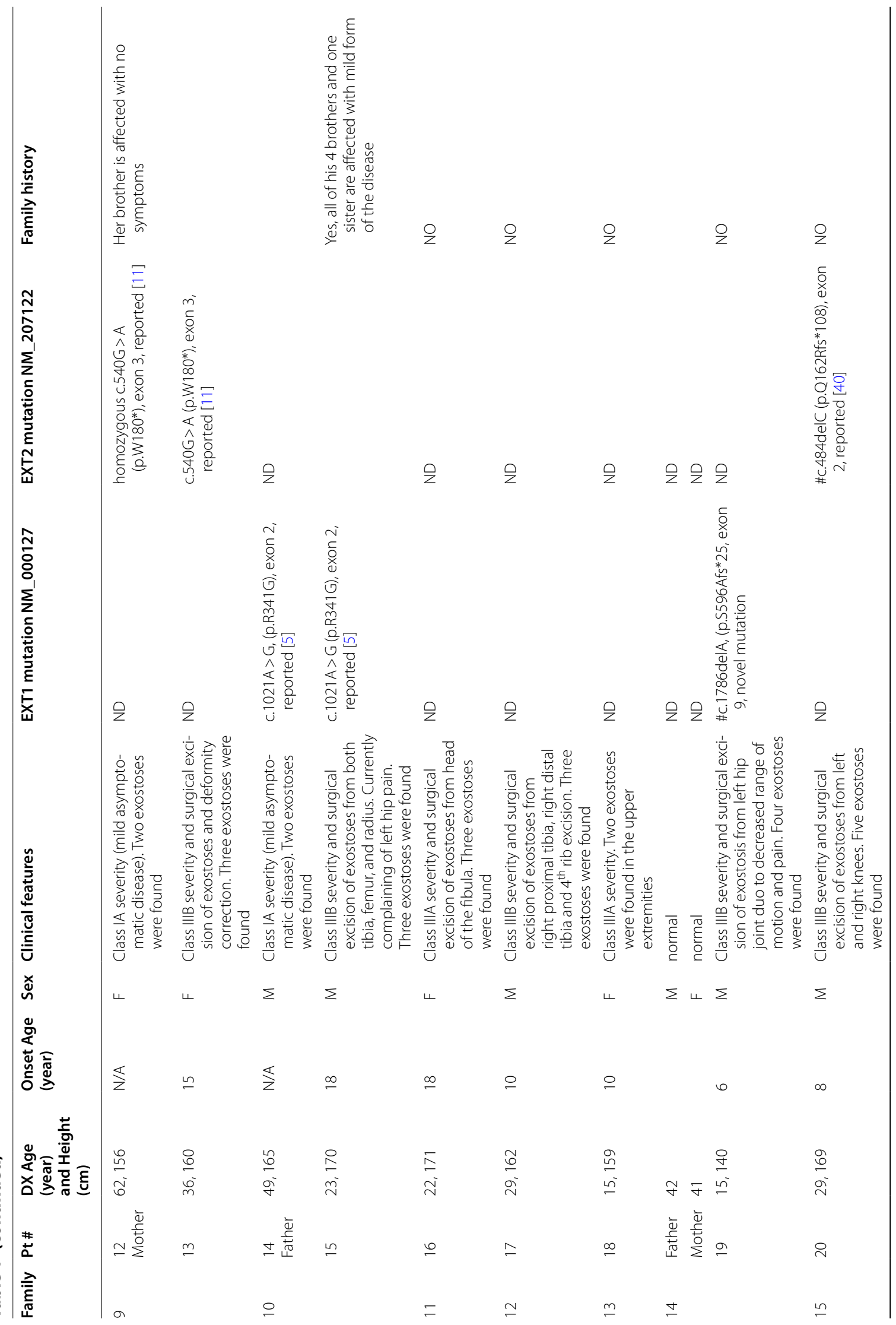




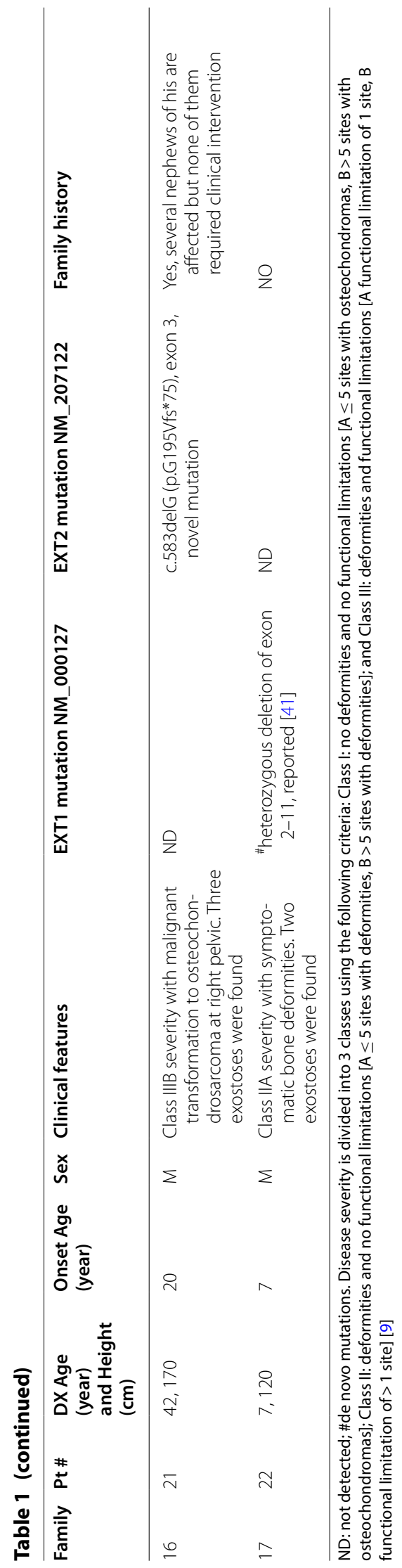


Table 2 EXT1 and EXT2 primer sequences and PCR conditions

\begin{tabular}{|c|c|c|c|c|c|c|}
\hline Exons & EXT1-Forward & EXT1-Reverse & $\begin{array}{l}\text { Annealing } \\
\left({ }^{\circ} \mathrm{C}\right)\end{array}$ & EXT2-Forward & EXT2-Reverse & $\begin{array}{l}\text { Annealing } \\
\left({ }^{\circ} \mathrm{C}\right)\end{array}$ \\
\hline Exon 1a & $\begin{array}{l}\text { 5'ggaaaggcatccagagaa- } \\
\text { ggt-3' }\end{array}$ & $\begin{array}{l}\text { 5'-cttgcaaagggtgaaatc- } \\
\text { gaa-3' }\end{array}$ & 58 & $5^{\prime}$-cagtccgctccttcctttcct-3' & $\begin{array}{l}\text { 5'-agtgcctggeccaacat- } \\
\text { gac-3 }\end{array}$ & 62 \\
\hline Exon $1 b$ & $5^{\prime}$-ttcgttccttgggatcaatt-3' & $\begin{array}{l}5^{\prime} \text {-cctgtcctgggatgatc- } \\
\text { ctta-3' }\end{array}$ & 56 & & & \\
\hline Exon 1c & $5^{\prime}$-ggcacttggcctgactacac-3' & $5^{\prime}$-gggctcatccgecctcacc-3' & 58 & & & \\
\hline Exon 2 & $5^{\prime}$-gagttgctttgcgtaaattca-3' & $5^{\prime}$-acaccttctctttagctatcc- $3^{\prime}$ & 58 & 5'-aggttgaatagtcttttcaag-3' & $\begin{array}{l}5^{\prime} \text {-ggaaaccaactcaagagca- } \\
\text { gaa-3' }\end{array}$ & 54 \\
\hline Exon 3 & $5^{\prime}$-cagtcattgagtttgtactga-3' & $5^{\prime}$-gagctgaccttttggattcat-3' & 58 & $5^{\prime}$-ggatccttgatagttgttgtc- $3^{\prime}$ & $5^{\prime}$-caattctgattacaaagtatg-3' & 58 \\
\hline Exon 4 & $\begin{array}{l}5^{\prime} \text {-ctatatgctagaagc- } \\
\text { caaatg-3' }\end{array}$ & $\begin{array}{l}5^{\prime} \text {-cactggaccaatcaca- } \\
\text { catcc-3' }\end{array}$ & 56 & $5^{\prime}$-gactcagtaattcctgttcct-3' & $\begin{array}{l}5^{\prime} \text {-gcctcaaggaccctacc- } \\
\text { ctg-3' }\end{array}$ & 56 \\
\hline Exon 5 & $\begin{array}{l}5^{\prime} \text {-gtcactactctgactgc- } \\
\text { cacc- } 3^{\prime}\end{array}$ & $\begin{array}{l}5^{\prime} \text {-tgcagggtgttagatg- } \\
\text { gacc-3' }\end{array}$ & 58 & $\begin{array}{l}5^{\prime} \text {-ctggtaaggaaacact- } \\
\text { tactg-3' }\end{array}$ & $\begin{array}{l}5^{\prime} \text {-ctagttgcatgct- } \\
\text { gaaaacaa-3 }\end{array}$ & 58 \\
\hline Exon 6 & $\begin{array}{l}5^{\prime} \text {-ctccagcatgaggcagcg- } \\
\text { gag-3' }\end{array}$ & $\begin{array}{l}5^{\prime} \text {-gggtatgatgttaga- } \\
\text { gaagt-3' }\end{array}$ & 58 & $\begin{array}{l}5^{\prime} \text {-cagtattgcttggcgt- } \\
\text { caacc-3' }\end{array}$ & $\begin{array}{l}5^{\prime} \text {-tgtagtagttcttgaac- } \\
\text { cagg- } 3^{\prime}\end{array}$ & 58 \\
\hline Exon 7 & $5^{\prime}$-ctctttctgtctctgagaaga--3' & $\begin{array}{l}\text { 5'-gaacagggagaaga- } \\
\text { tatctag-3' }\end{array}$ & 58 & $5^{\prime}$-gatgttgtttctgcttgtgaa-3' & $\begin{array}{l}5^{\prime} \text {-gatctagtggaggaag- } \\
\text { taaac- } 3^{\prime}\end{array}$ & 56 \\
\hline Exon 8 & $\begin{array}{l}5^{\prime} \text {-caggtgaggatgggaga- } \\
\text { attg-3' }\end{array}$ & $\begin{array}{l}5^{\prime} \text {-gaagcattagcatcgtg- } \\
\text { caac- } 3^{\prime}\end{array}$ & 58 & $\begin{array}{l}5^{\prime} \text {-aaaggaattagcctaac- } \\
\text { ctgg--3' }\end{array}$ & $5^{\prime}$-cctttacaattgtagtacatt-3' & 58 \\
\hline Exon 9 & $5^{\prime}$-gaattaatgtttcgccacagt-3' & $5^{\prime}$-ctgttaacaagatttggcctt-3' & 58 & $\begin{array}{l}5^{\prime} \text {-caccaagcctgccat- } \\
\text { gtttgg-3' }\end{array}$ & $\begin{array}{l}5^{\prime} \text {-ggtattgctattgacaaa- } \\
\text { gca-3' }\end{array}$ & 58 \\
\hline Exon 10 & $\begin{array}{l}5^{\prime} \text {-gacatgtttagg- } \\
\text { gattcaaag-3' }\end{array}$ & $5^{\prime}$-ctcctcattatatgctcctgg-3' & 58 & $5^{\prime}$-gctgattctcccatctcattt-3' & $5^{\prime}$-ttacgcacaccttttggactc-3' & 58 \\
\hline Exon 11 & $5^{\prime}$-gctgcttgctcatttgcctg--3' & $\begin{array}{l}5^{\prime} \text {-caggagttgagttct- } \\
\text { cattgg- } 3^{\prime}\end{array}$ & 58 & $\begin{array}{l}5^{\prime} \text {-gatggtttgaacctag- } \\
\text { gaagt-3' }\end{array}$ & $\begin{array}{l}5^{\prime} \text {-ctaagccctcttggcag- } \\
\text { gtat-3' }\end{array}$ & 58 \\
\hline Exon 12 & & & & $\begin{array}{l}5^{\prime} \text {-ccatgccttggctatgct- } \\
\text { gcc-3' }\end{array}$ & $\begin{array}{l}5^{\prime} \text {-gttacaagaacttcctag- } \\
\text { gct-3' }\end{array}$ & 58 \\
\hline Exon 13 & & & & $\begin{array}{l}5^{\prime} \text {-caacatctcagctta- } \\
\text { caacac-3' }\end{array}$ & $\begin{array}{l}5^{\prime} \text {-tatggctaccagctgct- } \\
\text { gtcc-3' }\end{array}$ & 58 \\
\hline Exon 14 & & & & $5^{\prime}$-ctctcaacctcttgaacatac-3' & $\begin{array}{l}5^{\prime} \text {-gtgcatgccaagatccaa- } \\
\text { gta-3' }\end{array}$ & 58 \\
\hline
\end{tabular}

PCR conditions: $50 \mathrm{ng}$ of DNA were denatured at $95^{\circ} \mathrm{C}$ for 5 min on initial cycle followed by 35 cycles of denaturation, annealing, and extension at 1 min on each step

\section{Analysis of copy number variation}

Copy number variation in genomic DNA was analyzed by MLPA (Multiplex Ligation-dependent Probe Amplification) analysis as described previously [12].

\section{Results}

EXT1 and EXT2 mutations were identified in 13 out of 17 (77\%) unrelated patients and 18 of total 22 patients (82\%) (Table 1). Among them, 7 were EXT1 mutations including 1 recurrent mutation in one related family member (35\%, 6/17 unrelated patients or $32 \%, 7 / 22$ total patients); 11 were EXT2 mutations including 4 recurrent mutations from 4 family members $(41 \%, 7 / 17$ unrelated patients, or $50 \%, 11 / 22$ total patients) (Table 1). Among 13 different mutations, 7 were previously reported mutations (Table 1, Fig. 2) and 6 were novel mutations (Fig. 3). Three novel mutations occurred in the EXT1: c.739G > T (p.E247*), c.1319delG (p.R440Lfs*4), and c.1786delA (p.S596Afs"25) and 3 in the EXT2: c.541delG (p.D181Ifs"89), c.583delG (p.G195Vfs*75) and a gross homozygous deletion of approximately $10 \mathrm{~kb}$ including promoter and exon 1 (Table 1, Fig. 3). In the patient with the homozygous deletion, we were able to amplify exon 2 to 14 successfully, but could not amplify exon 1 and its $5^{\prime}$ untranslated region of about $10 \mathrm{~kb}$, indicating a $10 \mathrm{~kb}$ deletion of exon 1 and the promoter region. Five patients from unrelated families were found to have mutations without any family history of the disease and these mutations were thus de novo mutations $(29 \%, 5 / 17)$. Interestingly, 4 of them were also novel mutations (Table 1 ). MLPA analysis was performed to detect large deletions in the patients who had no mutation detected by PCRsequencing analysis. One large heterozygous deletion involving exons 2-11 was detected (Table 1). Among 13 different mutations, 6 were single nucleotide deletions, 3 were nonsense mutations, 1 missense mutation, 1 splice donor site mutation, and 2 large deletions. Therefore, all the mutations except for one missense mutation (92\%, $12 / 13)$ are predicted to result in frameshift and truncated proteins devoid of enzymatic activity. 


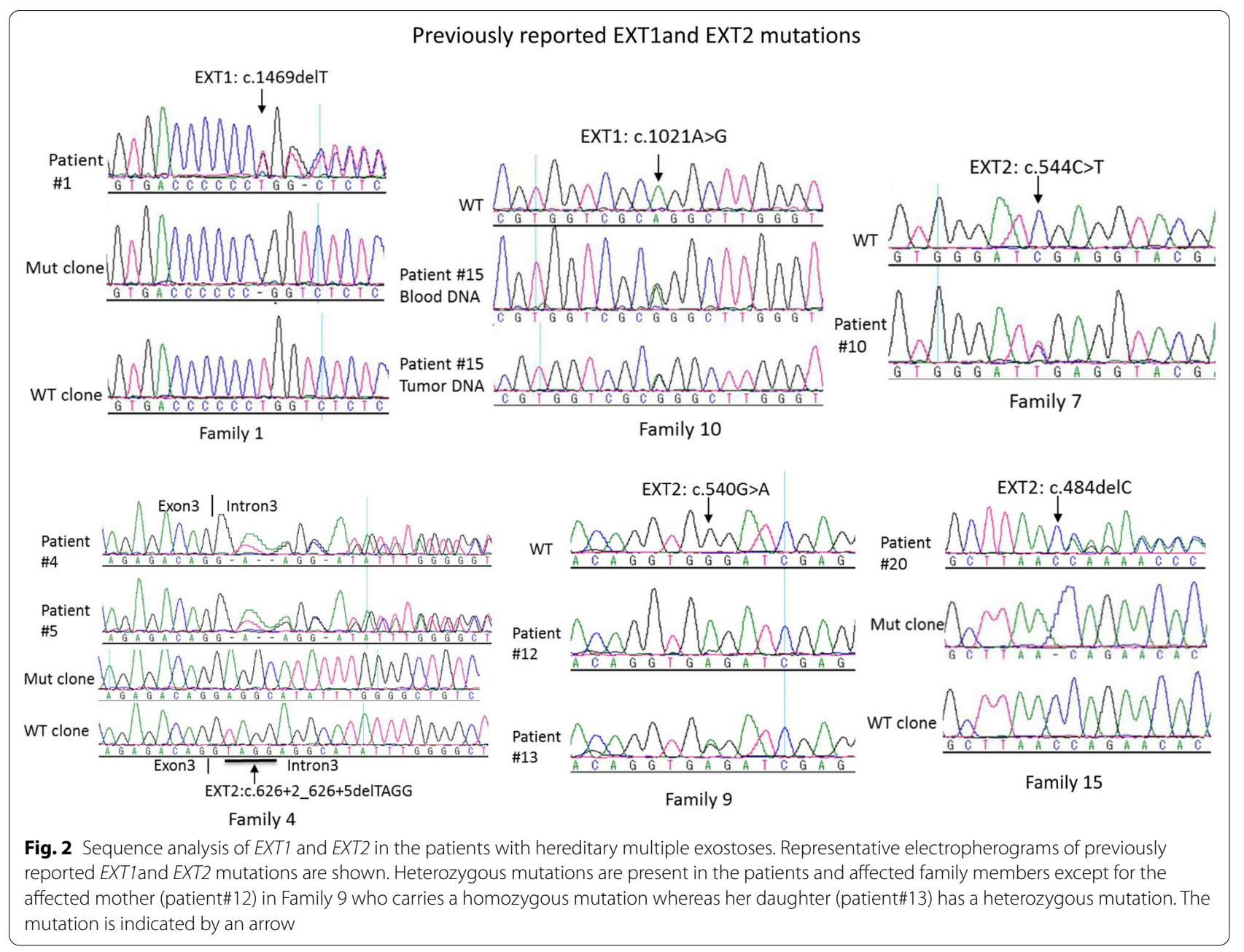

Compared to the patients with EXT2 mutations, most patients with EXT1 mutations had more severe phenotype and required surgery. Germline homozygous EXT2 mutations were identified in two patients (patient \#11 and 12 in Table 1) who presented only mild asymptomatic disease and no clinical intervention was required. Furthermore, significant heterogeneity in clinical presentations were demonstrated among family members carrying the same mutations. For example as shown in Table 1, patient\#12 carried a homozygous EXT2 c.540G > A mutation with only mild asymptomatic disease whereas her daughter (patient\#13) had a heterozygous EXT2 c.540G > A mutation and required multiple operations to remove exostosis and correct bone deformity.

\section{Discussion}

In the present study, we have studied EXT1 and EXT2 mutation spectrum in 22 patients from 17 unrelated Saudi families. Disease-causing mutations are identified in $77 \%$ of patients (13/17) including 6 novel mutations.
The frequency of EXT1 mutation is lower than EXT2: $35 \%$ (6/17) for EXT1 and 41\% (7/17) for EXT2. Twentynine percent of patients $(5 / 17)$ have de novo mutations, which account for $39 \%$ (5/13) of mutations identified.

EXT1 and EXT2 encode for 746 and 718 amino acids glycosyltransferases, respectively, that are involved in the chain elongation step of heparan sulfate biosynthesis in the cell's Golgi apparatus [13-15]. Heparan sulfate is an essential component of cell surface and matrixassociated proteoglycans, which function by interacting with key heparin sulfate-binding proteins such as bone morphogenetic proteins (BMPs), fibroblast growth factor (FGF), Hedgehog and Wnt signaling proteins to regulate skeletal growth and morphogenesis [16, 17]. The growth plate of long bones is known to contain large amounts of heparan sulfate proteoglycans, such as syndecan, glypican and perlecan during cartilage development [18]. The glycosyltransferases are ubiquitously expressed type II transmembrane glycoproteins with transmembrane domain at the $\mathrm{N}$-terminal end, an 


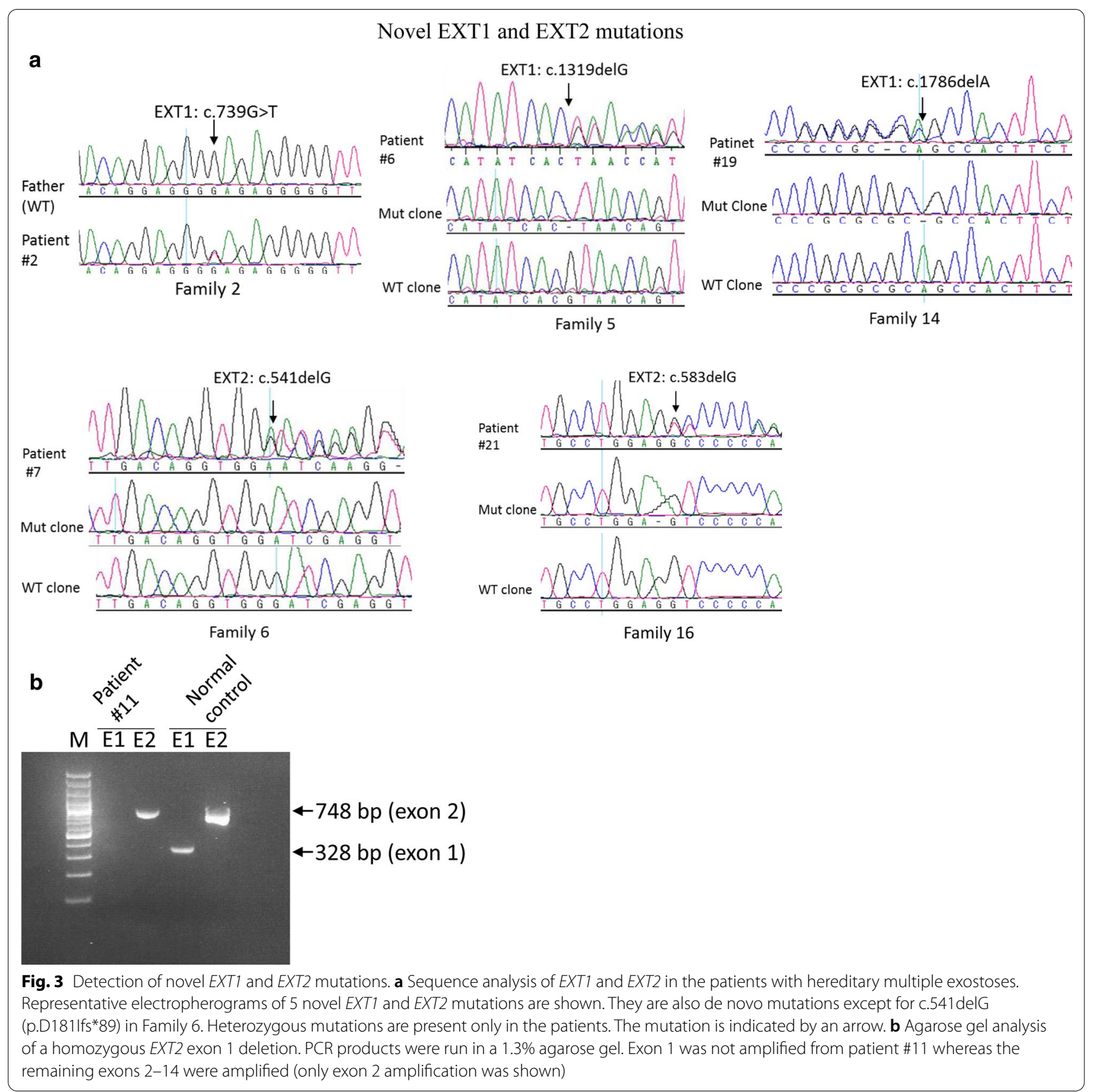

exostosin interaction domain in the center and a catalytic domain at the C-terminal end. EXT1 and EXT2 form a hetero-oligomeric complex in vivo that leads to accumulation of both proteins in the Golgi apparatus. The Golgi-localized EXT1/EXT2 complex possesses substantially higher glycosyltransferase activity than EXT1 or EXT2 alone, suggesting that the hetero-oligomeric complex is the biological form of the enzyme for heparan sulfate biosynthesis and explains mutations in either EXT1 or EXT2 gene would result in the loss of enzymatic activity and disease development [19-21].

HME is a rare childhood-onset skeletal disease caused by germline mutations in the tumor suppressor gene EXT1 or EXT2. Most HME patients carry a germline heterozygous loss-of-function mutation in the EXT1 or EXT2 and display a 50\% reduction of systemic heparin sulfate [22]. It is generally believed that exostosis formation and associated defects, such as growth retardation 
and skeletal deformities, require loss-of-heterozygosity or a second hit in the affected cells [23, 24]. Mice with single heterozygous deletion of Ext $1 \pm$ or Ext $2 \pm$ are normal. Compound heterozygous Ext1+/-; Ext2+/- deletion mice and conditional Ext1 knockout mice display multiple osteochondromas and closely resemble human HME [25-27]. However, a second hit in the EXT1 or EXT2 gene are not common in most cases (more than $60 \%$ ), suggesting that mechanisms other than EXT genetic alterations may play a role in the disease development $[28,29]$. In our patients, homozygous germline EXT2 mutations were detected in two patients (patient \#11 and 12 (Table 1, Fig. 2 and 3b). To our knowledge, homozygous germline EXT1/EXT2 mutations have not been reported in the literature. Interestingly, the presence of homozygous germline EXT2 mutations does not associated with severity of the disease since both patients have mild asymptomatic disease. Furthermore, no significant difference in clinical presentations or disease progression is found between patients with mutation and those without mutation. In fact, significant heterogeneity in disease development and progression are observed among patients with or without mutations. This is even demonstrated among family members carrying the same mutations, indicating epigenetic and/or environmental factors may contribute to the disease development and progression.

It has been reported that EXT1 mutation is more common (about 65\%) than EXT2 (about 30\%) and its protein is less tolerant to the damaging mutations $[5,30]$. This may explain EXT1 mutations usually result in more severe disease phenotype. Indeed, most of our patients with EXT1 mutations have more severe phenotype and require surgery. In contrast to the higher EXT1 mutation rate reported in the literature, the frequency of EXT1 mutation appears to be lower than EXT2 in our current study. It remains to be determined whether this is due to small sample size or population-specific.

The most common type of mutations in the EXT1 and EXT2 genes are inactivating mutations, such as frameshift, nonsense, and splice-site mutations [6, $31,32]$. Based on the HGMD ${ }^{\circledR}$ Professional 2020.1 (Accessed on August 10, 2020), approximately 79\% EXT1 mutations and $75 \%$ EXT2 mutations are inactivating mutations: frameshift $47 \%(268 / 566)$, nonsense $22 \%(123 / 566)$, splice-site $10 \%(58 / 565)$ in the EXT1; frameshift $43 \%(119 / 278)$, nonsense $22 \%$ (60/278), splice-site $10 \%(29 / 278)$ in the EXT2. The remaining EXT1 mutations are missense $(12 \%, 68 / 566)$, gross deletions $(7 \%, 40 / 566)$, and complex rearrangements $(1 \%$, 7/566) whereas remaining EXT2 mutations are missense $(14 \%, 40 / 278)$ and gross deletions $(9 \%, 26 / 278)$. In our current study of Saudi patients, the overall frequency of inactivating EXT1 and EXT2 mutations is $92 \%$ (12/13): frameshift $46 \%$ (6/13), nonsense $23 \%$ $(3 / 13)$, splice-site $8 \%(1 / 13)$, gross deletion $(15 \%, 2 / 13)$, which is higher than the overall rate documented in the HGMD $(78 \%, 657 / 843)$. This is probably due to small sample size in our study. All of these mutations $(92 \%$, $11 / 12$ ) are predicted to result in truncated proteins devoid of enzymatic activity. Four patients were not found to have EXT1/EXT2 mutations (Patient\# 3, 16, $17,18)$. Although HME may be confused with enchondroma which is a benign cartilage tumor, enchondroma often affects the cartilage that lines the inside of long bones in the hands and feet. The clinical and radiographic features of our patients (multiple bony outgrowths on the external surface in the metaphysis of long bones) do not support the diagnosis of enchondromas. The involvement of additional genes other than EXT1/EXT2 or other mechanisms may contribute to the disease development $[7,8]$.

De novo EXT1 and EXT2 mutations have been reported to account for approximately $10 \%$ of patients [5, 33]. However, higher frequency are reported in other populations: Polish (21\%) [34], English (33\%) [35], and Chinese (30\%) [36]. The high de novo mutation rate in the Saudi patients (29\%) indicates that family history should not be relied upon heavily in the diagnosis of the disease.

\section{Conclusions}

We have investigated genetic defects of EXT1 and EXT2 in the Saudi HME patients. EXT1 and EXT2 mutations are detected in $77 \%$ of patients. De novo EXT1 and EXT2 mutations are common. The current study further expands the mutation spectrum of HME.

\section{Abbreviations}

HME: Hereditary Multiple Exostoses; MO: Multiple Osteochondromas; EXT1: Exostosin glycosyltransferase 1; EXT2: Exostosin glycosyltransferase 2; PCR: Polymerase chain reaction; MLPA: Multiplex ligation-dependent probe amplification.

\section{Acknowledgements}

Not applicable.

\section{Authors' contributions}

Study design: ZA, LA, and YS; Patient data collection: ZA, LA, RP, and TA; Laboratory investigation: RAA, HAB, and MZ. Data analysis: ZA, LA, MZ, BFM, and YS; Drafted manuscript: ZA and YS; Revised manuscript: LA, RP, TA, MZ, and BFM.

All authors read and approved the final manuscript.

\section{Funding}

This study is supported by a KACST Biotech grant 13-MED1765-20.

Availability of data and materials

Data supporting the findings of the study are included in the manuscript. 


\section{Ethics approval and consent to participate}

The study was approved by the Ethics Committee of King Faisal Specialist Hospital and Research Centre (RAC \#2170 027). Written consent was obtained from the patients or guardian of the patients before enrollment.

\section{Consent for publication}

Not applicable.

\section{Competing interests}

The authors declare that they have no competing interests.

\begin{abstract}
Author details
${ }^{1}$ Department of Orthopedics, King Faisal Specialist Hospital and Research Center, Riyadh, Saudi Arabia. ${ }^{2}$ College of Medicine, Alfaisal University, Riyadh, Saudi Arabia. ${ }^{3}$ Department of Genetics, MBC 3, Centre for Genomic Medicine, King Faisal Specialist Hospital and Research Center, P.O. Box 3354, Riyadh 11211, Saudi Arabia.
\end{abstract}

Received: 12 August 2020 Accepted: 11 February 2021

Published online: 25 February 2021

\section{References}

1. Schmale GA, Conrad EU 3rd, Raskind WH. The natural history of hereditary multiple exostoses. J Bone Joint Surg Am. 1994;76(7):986-92.

2. Pacifici M. Hereditary multiple exostoses: new insights into pathogenesis, clinical complications, and potential treatments. Curr Osteoporos Rep. 2017;15(3):142-52.

3. Czajka CM, DiCaprio MR. What is the proportion of patients with multiple hereditary exostoses who undergo malignant degeneration? Clin Orthop Relat Res. 2015;473(7):2355-61.

4. Bovée JV. Multiple osteochondromas. Orphanet J Rare Dis. 2008;3:3.

5. Jennes I, Pedrini E, Zuntini M, Mordenti M, Balkassmi S, Asteggiano CG, Casey B, Bakker B, Sangiorgi L, Wuyts W. Multiple osteochondromas: mutation update and description of the multiple osteochondromas mutation database (MOdb). Hum Mutat. 2009;30(12):1620-7.

6. Wuyts W, Van Hul W. Molecular basis of multiple exostoses: mutations in the EXT1 and EXT2 genes. Hum Mutat. 2000;15(3):220-7.

7. Szuhai K, Jennes I, de Jong D, Bovée JV, Wiweger M, Wuyts W, Hogendoorn PC. Tiling resolution array-CGH shows that somatic mosaic deletion of the EXT gene is causative in EXT gene mutation negative multiple osteochondromas patients. Hum Mutat. 2011;32(2):E2036-2049.

8. Waaijer CJ, Winter MG, Reijnders CM, de Jong D, John Ham S, Bovée JV, Szuhai K. Intronic deletion and duplication proximal of the EXT1 gene: a novel causative mechanism for multiple osteochondromas. Genes Chromosomes Cancer. 2013;52(4):431-6.

9. Mordenti M, Ferrari E, Pedrini E, Fabbri N, Campanacci L, Muselli M, Sangiorgi L. Validation of a new multiple osteochondromas classification through Switching Neural Networks. Am J Med Genet A. 2013;161A(3):556-60.

10. Cebeci AN, Zou M, BinEssa HA, Alzahrani AS, Al-Rijjal RA, Al-Enezi AF, Al-Mohanna FA, Cavalier E, Meyer BF, Shi Y: Mutation of SGK3, a novel regulator of renal phosphate transport, causes autosomal dominant hypophosphatemic rickets. J Clin Endocrinol Metab 2020, 105(6).

11. Sarrión P, Sangorrin A, Urreizti R, Delgado A, Artuch R, Martorell L, Armstrong J, Anton J, Torner F, Vilaseca MA, et al. Mutations in the EXT1 and EXT2 genes in Spanish patients with multiple osteochondromas. Sci Rep. 2013:3:1346.

12. Raef H, Zou M, Baitei EY, Al-Rijjal RA, Kaya N, Al-Hamed M, Monies D, AbuDheim NN, Al-Hindi $\mathrm{H}$, Al-Ghamdi MH, et al. A novel deletion of the MEN1 gene in a large family of multiple endocrine neoplasia type 1 (MEN1) with aggressive phenotype. Clin Endocrinol (Oxf). 2011;75(6):791-800. https://doi.org/10.1111/j.1365-2265.2011.04134.x.

13. Nadanaka S, Kitagawa H. Heparan sulphate biosynthesis and disease. J Biochem. 2008;144(1):7-14.

14. Pacifici M. The pathogenic roles of heparan sulfate deficiency in hereditary multiple exostoses. Matrix Biol. 2018;71-72:28-39.

15. Lind T, Tufaro F, McCormick C, Lindahl U, Lidholt K. The putative tumor suppressors EXT1 and EXT2 are glycosyltransferases required for the biosynthesis of heparan sulfate. J Biol Chem. 1998;273(41):26265-8.
16. Nagarajan A, Malvi P, Wajapeyee N. Heparan sulfate and heparan sulfate proteoglycans in cancer initiation and progression. Front Endocrinol (Lausanne). 2018:9:483.

17. Huegel J, Sgariglia F, Enomoto-Iwamoto M, Koyama E, Dormans JP, Pacifici M. Heparan sulfate in skeletal development, growth, and pathology: the case of hereditary multiple exostoses. Dev Dyn. 2013;242(9):1021-32.

18. Farach-Carson MC, Hecht JT, Carson DD. Heparan sulfate proteoglycans: key players in cartilage biology. Crit Rev Eukaryot Gene Expr. 2005;15(1):29-48

19. Busse M, Feta A, Presto J, Wilén M, Grønning M, Kjellén L, Kusche-Gullberg M. Contribution of EXT1, EXT2, and EXTL3 to heparan sulfate chain elongation. J Biol Chem. 2007;282(45):32802-10.

20. McCormick C, Duncan G, Goutsos KT, Tufaro F. The putative tumor suppressors EXT1 and EXT2 form a stable complex that accumulates in the Golgi apparatus and catalyzes the synthesis of heparan sulfate. Proc Natl Acad Sci USA. 2000;97(2):668-73.

21. Senay C, Lind T, Muguruma K, Tone Y, Kitagawa H, Sugahara K, Lidholt K, Lindahl U, Kusche-Gullberg M. The EXT1/EXT2 tumor suppressors: catalytic activities and role in heparan sulfate biosynthesis. EMBO Rep. 2000;1(3):282-6.

22. Anower EKMF, Matsumoto K, Habuchi H, Morita H, Yokochi T, Shimizu K, Kimata K. Glycosaminoglycans in the blood of hereditary multiple exostoses patients: half reduction of heparan sulfate to chondroitin sulfate ratio and the possible diagnostic application. Glycobiology. 2013;23(7):865-76. https://doi.org/10.1093/glycob/cwt1024 (Epub 2013 Mar 1020)

23. Reijnders CM, Waaijer CJ, Hamilton A, Buddingh EP, Dijkstra SP, Ham J, Bakker E, Szuhai K, Karperien M, Hogendoorn PC, et al. No haploinsufficiency but loss of heterozygosity for EXT in multiple osteochondromas. Am J Pathol. 2010;177(4):1946-57.

24. Hameetman L, Szuhai K, Yavas A, Knijnenburg J, van Duin M, van Dekken $\mathrm{H}$, Taminiau AH, Cleton-Jansen AM, Bovee JV, Hogendoorn PC. The role of EXT1 in nonhereditary osteochondroma: identification of homozygous deletions. J Natl Cancer Inst. 2007;99(5):396-406.

25. Jones KB, Piombo V, Searby C, Kurriger G, Yang B, Grabellus F, Roughley PJ, Morcuende JA, Buckwalter JA, Capecchi MR, et al. A mouse model of osteochondromagenesis from clonal inactivation of Ext1 in chondrocytes. Proc Natl Acad Sci USA. 2010;107(5):2054-9. https://doi. org/10.1073/pnas.0910875107 (Epub 0910872009 Dec 0910875122).

26. Matsumoto Y, Matsumoto K, Irie F, Fukushi J, Stallcup WB, Yamaguchi Y. Conditional ablation of the heparan sulfate-synthesizing enzyme Ext1 leads to dysregulation of bone morphogenic protein signaling and severe skeletal defects. J Biol Chem. 2010;285(25):19227-34. https://doi. org/10.11074/jbc.M19110.105338 (Epub 102010 Apr 105319).

27. Sgariglia F, Candela ME, Huegel J, Jacenko O, Koyama E, Yamaguchi Y, Pacifici M, Enomoto-Iwamoto M. Epiphyseal abnormalities, trabecular bone loss and articular chondrocyte hypertrophy develop in the long bones of postnatal Ext1-deficient mice. Bone. 2013;57(1):220-31. https:// doi.org/10.1016/j.bone.2013.1008.1012 (Epub 2013 Aug 1017).

28. Zuntini M, Pedrini E, Parra A, Sgariglia F, Gentile FV, Pandolfi M, Alberghini M, Sangiorgi L. Genetic models of osteochondroma onset and neoplastic progression: evidence for mechanisms alternative to EXT genes inactivation. Oncogene. 2010;29(26):3827-34.

29. de Andrea CE, Reijnders CM, Kroon HM, de Jong D, Hogendoorn PC, Szuhai K, Bovée JV. Secondary peripheral chondrosarcoma evolving from osteochondroma as a result of outgrowth of cells with functional EXT. Oncogene. 2012;31(9):1095-104.

30. Cousminer DL, Arkader A, Voight BF, Pacifici M, Grant SFA. Assessing the general population frequency of rare coding variants in the EXT1 and EXT2 genes previously implicated in hereditary multiple exostoses. Bone. 2016;92:196-200

31. Ishimaru D, Gotoh M, Takayama S, Kosaki R, Matsumoto Y, Narimatsu H, Sato T, Kimata K, Akiyama H, Shimizu K et al: Large-scale mutational analysis in the EXT1 and EXT2 genes for Japanese patients with multiple osteochondromas. BMC Genet 2016, 17:52. doi:https://doi.org/10.1186/ s12863-12016-10359-12864.

32. Sarrion P, Sangorrin A, Urreizti R, Delgado A, Artuch R, Martorell L, Armstrong J, Anton J, Torner F, Vilaseca MA et al. Mutations in the EXT1 and EXT2 genes in Spanish patients with multiple osteochondromas. Sci Rep 2013, 3:1346. doi:https://doi.org/10.1038/srep01346. 
33. Ciavarella M, Coco M, Baorda F, Stanziale P, Chetta M, Bisceglia L, Palumbo P, Bengala M, Raiteri P, Silengo M, et al. 20 novel point mutations and one large deletion in EXT1 and EXT2 genes: report of diagnostic screening in a large Italian cohort of patients affected by hereditary multiple exostosis. Gene. 2013;515(2):339-48.

34. Jamsheer A, Socha M, Sowińska-Seidler A, Telega K, TrzeciakT, Latos-Bieleńska A. Mutational screening of EXT1 and EXT2 genes in Polish patients with hereditary multiple exostoses. J Appl Genet. 2014:55(2):183-8.

35. Philippe C, Porter DE, Emerton ME, Wells DE, Simpson AH, Monaco AP. Mutation screening of the EXT1 and EXT2 genes in patients with hereditary multiple exostoses. Am J Hum Genet. 1997;61(3):520-8.

36. Kang QL, Xu J, Zhang Z, He JW, Fu WZ, Zhang ZL. Mutation screening for the EXT1 and EXT2 genes in Chinese patients with multiple osteochondromas. Arch Med Res. 2013;44(7):542-8.

37. Ahn J, Ludecke HJ, Lindow S, Horton WA, Lee B, Wagner MJ, Horsthemke $B$, Wells DE. Cloning of the putative tumour suppressor gene for hereditary multiple exostoses (EXT1). Nat Genet. 1995;11(2):137-43.

38. Li Y, Wang J, Wang Z, Tang J, Yu T. A genotype-phenotype study of hereditary multiple exostoses in forty-six Chinese patients. BMC Med Genet. 2017;18(1):126.
39. Dobson-Stone C Cox RD, Lonie L, Southam L, Fraser M, Wise C, Bernier F, Hodgson S, Porter DE, Simpson AH, et al. Comparison of fluorescent single-strand conformation polymorphism analysis and denaturing high-performance liquid chromatography for detection of EXT1 and EXT2 mutations in hereditary multiple exostoses. Eur J Hum Genet. 2000;8(1):24-32.

40. Jennes I, Entius MM, Van Hul E, Parra A, Sangiorgi L, Wuyts W. Mutation screening of EXT1 and EXT2 by denaturing high-performance liquid chromatography, direct sequencing analysis, fluorescence in situ hybridization, and a new multiplex ligation-dependent probe amplification probe set in patients with multiple osteochondromas. J Mol Diagn. 2008;10(1):85-92.

41. Jennes I, de Jong D, Mees K, Hogendoorn PC, Szuhai K, Wuyts W: Breakpoint characterization of large deletions in EXT1 or EXT2 in 10 multiple osteochondromas families. BMC Med Genet 2011, 12:85 doi:https://doi. org/10.1186/1471-2350-1112-1185.

\section{Publisher's Note}

Springer Nature remains neutral with regard to jurisdictional claims in published maps and institutional affiliations.
Ready to submit your research? Choose BMC and benefit from:

- fast, convenient online submission

- thorough peer review by experienced researchers in your field

- rapid publication on acceptance

- support for research data, including large and complex data types

- gold Open Access which fosters wider collaboration and increased citations

- maximum visibility for your research: over $100 \mathrm{M}$ website views per year

At BMC, research is always in progress.

Learn more biomedcentral.com/submissions 